\title{
Banana peel biochar as alternative source of potassium for plant productivity and sustainable agriculture
}

\author{
Mahmuda Islam $^{1} \cdot$ M. Halder ${ }^{1}$ Md. A. B. Siddique ${ }^{2} \cdot$ S. A. A. Razir ${ }^{1}$ - S. Sikder ${ }^{1}$ J. C. Joardar ${ }^{1}$ (D)
}

Received: 20 March 2019 / Accepted: 30 October 2019 / Published online: 12 November 2019

(c) The Author(s) 2019

\begin{abstract}
Purpose Biochar addition to soil is immensely beneficial for increasing plant productivity and $\mathrm{C}$ sequestration, attenuating nutrient leaching loss, counteracting heavy metal contamination and organic waste triggered environmental pollution. To understand the sustainable benefits of biochar, two pot experiments were conducted under net house condition in Khulna University, Bangladesh.

Methods Biochar was prepared from banana peel waste through slow pyrolysis process under limited oxygen condition. Three lower rates (1,2 and 3\%) of banana peel biochar (BPB) were added with agricultural soil along with control with three replications for each. After incorporation of BPB into soil, pots were kept under field condition for 7 days and then the seeds of Ipomoea aquatica were sown. Plants were harvested after 42 days from seeds sowing and plant height, leaf number, fresh weight, and dry weight were measured. Another pot experiment was also conducted under sand medium to test the BPB as K-rich soil amendment where $\mathrm{K}$ was applied from two different sources ( $\mathrm{KCl}$ and $\mathrm{BPB}$ ) along with control. Seeds of Cucurbita moschata were sown and 40 days after seed sowing, K deficiency was observed in control treatments.

Results Banana peel biochar was found to be rich in K content. Plant productivity and above-ground biomass were reduced in $1 \%$ BPB treatments, but increased in 2 and 3\% BPB treatments as compared to control but statistically insignificant $(p<0.05)$. In case of second experiment, $\mathrm{K}$ deficiency symptoms were observed in 40 days aged Cucurbita moschata seedlings under control treatments, whereas no $\mathrm{K}$ deficiency symptom was noticed in plants grown under $\mathrm{K}$ supplied from both $\mathrm{KCl}$ and BPB. Moreover, the plant grown with BPB was found healthy, stronger and greener in appearance.

Conclusion This positive influence of BPB on plant growth suggests the alternative way to overcome the use of chemical fertilizer and effective way of utilization of agricultural wastes through recycling.
\end{abstract}

Keywords Biochar $\cdot$ Banana peel $\cdot$ Ipomoea aquatic $\cdot$ Agronomic parameters $\cdot$ Potassium $\cdot$ Deficiency

\section{Introduction}

Biochar is a carbon-rich product defined as 'a solid material obtained from the thermo-chemical conversion of biomass in an oxygen limited environment' (IBI (International Biochar Initiative) 2012). Recently, it has become a major part of studies because of its unique feature which can help to mitigate climate change and improve soil quality (Novak

J. C. Joardar

jcjoardar@yahoo.com

1 Soil, Water and Environment Discipline, Khulna University, Khulna 9208, Bangladesh

2 Institute of National Analytical Research and Services (INARS), Bangladesh Council of Scientific and Industrial Research (BCSIR), Dhaka 1205, Bangladesh et al. 2009). Biochar has a range of functions regarding environmental management and has been used as an efficient adsorbent to adsorb organic toxic pollutants and heavy metals (Lohmann et al. 2005; Mohan et al. 2007; Lu et al. 2015).

It has a great positive impact on agriculture and the capacity to remediate contaminating soils through the improvement of soil physiochemical properties (Ventura et al. 2012; Alburquerque et al. 2013), reduction of nutrient leaching (Sika and Hardie 2014), and the enhancement of nutrient availability (Reverchon et al. 2014). Biochar can also be used for liming (Van Zwieten et al. 2010), raising water retention capacity (Novak et al. 2012), enhancing soil microbial activity (Warnock et al. 2007), protecting soil from indigenous pathogens (Bonanomi et al. 2015), improve soil quality, plant growth and energy production as well (Marris 2006; Sohi et al. 2010; Waters et al. 2011). 
Moreover, biochar is a cost effective, environment friendly and sustainable agricultural material. Agricultural and forestry waste such as nutshells, rice husk (Carter et al. 2013), pinewood (Tian et al. 2017), orchard pruning biomass (Trupiano et al. 2017) are widely used for biochar production. One of the most economically important fruit crops in Bangladesh is Banana (Musa sapientam L.) both in homestead or commercial farming and approximately one million tons of bananas are produced annually (Hossain 2014). It is available throughout the year in Bangladesh and highly consumed one compared to other fruit crops. Banana peel which is considered as waste comprises about $18-20 \%$ of its body weight (Ledividich et al. 1976).

We took the attempt in recycling the banana peel waste through biochar production as a source of plant nutrient. There is limited research work regarding to banana peel biochar (BPB) application and effects on agronomic parameters of plant. Some research is available on the agronomic effects of different biochar, for example, rice husk, pinewood, pruning biomass, etc. (Carter et al. 2013; Tian et al. 2017; Trupiano et al. 2017). Previous studies were designed as $4 \%$ biochar application rate was the threshold limit (Carter et al. 2013; Helliwell 2015; Tian et al. 2017) but increased above-ground biomass of plants (Carter et al. 2013; Tian et al. 2017) and also had some reports of excess biochar application rate decreased yield relative to control (Asai et al. 2009; Hammond et al. 2013). Currently, little research works were dedicated regarding lower biochar application rate $(<4 \%)$ and its effects on agronomic plant growth parameters (Biederman and Harpole 2013; Qian et al. 2018). The aim of this study was to manage banana peel waste through recycling into an alternative means of plant nutrients as a form of biochar with potential benefits by increasing plant productivity when incorporated into agricultural soils.

\section{Materials and methods}

\section{Type of experiment}

In this research, pot experiment was conducted to evaluate the effect of BPB on the growth of Ipomoea aquatica. Ipomoea aquatica was taken as the test crop, because this plant is very common and popular. Moreover, it is convenient to grow in this area and very fruitful to observe the growth performance under different treatment.

\section{Collection of soil and banana peel waste}

Soil used in the experiment as the growth medium was collected from the surface of the agricultural field inside the Khulna University campus, Khulna, Bangladesh by following the procedure as suggested by USDA (1951). Banana
Table 1 Basic properties of soil used for the experiment

\begin{tabular}{ll}
\hline Properties & Results \\
\hline Textural class & Silty clay \\
& loam \\
& $(\mathrm{SCL})$ \\
$\mathrm{pH}$ & 7.80 \\
$\mathrm{EC}\left(\mathrm{dSm}^{-1}\right)$ & 1.29 \\
$\mathrm{OM}(\%)$ & 1.49 \\
Total $N(\%)$ & 0.09 \\
Available $\mathrm{P}\left(\mu \mathrm{g} \mathrm{g}^{-1}\right)$ & 21.36 \\
Available $\mathrm{K}\left(\mu \mathrm{g} \mathrm{g}^{-1}\right)$ & 0.03 \\
Available $\mathrm{S}\left(\mu \mathrm{g} \mathrm{g}^{-1}\right)$ & 59.39 \\
Available $\mathrm{Zn}\left(\mu \mathrm{g} \mathrm{g}^{-1}\right)$ & 0.68 \\
Available B $\left(\mu \mathrm{g} \mathrm{g}^{-1}\right)$ & 0.45 \\
\hline
\end{tabular}

Table 2 Chemical properties of $\mathrm{BPB}$

\begin{tabular}{ll}
\hline $\begin{array}{l}\text { Chemical proper- } \\
\text { ties (total) }\end{array}$ & Results (\%) \\
\hline $\mathrm{Na}$ & 14.19 \\
$\mathrm{~K}$ & 42.55 \\
$\mathrm{Ca}$ & 11.53 \\
$\mathrm{Mg}$ & 4.74 \\
$\mathrm{Fe}$ & 3.32 \\
$\mathrm{Mn}$ & 0.10 \\
$\mathrm{Zn}$ & 0.14 \\
$\mathrm{~N}$ & 0.95 \\
\hline
\end{tabular}

peel wastes were collected from nearby tea stalls inside the Khulna University campus.

\section{Soil sample preparation}

The collected soil sample was processed in the laboratory of Soil, Water and Environment Discipline of Khulna University. The sample was opened in the laboratory and air dried by spreading on a sheet of plastic paper. After air drying, the larger aggregates were gently broken by wooden hammer, then the soil sample was passed through a $0.5 \mathrm{~mm}$ sieve and some basic properties were analyzed (Table 1).

\section{Production of BPB}

Banana peel biochar was produced through slow pyrolysis process. Collected raw banana peels were passed through a very low oxygen-containing decomposer container heating through a gas stove for $2 \mathrm{~h}$ at about $400{ }^{\circ} \mathrm{C}$ temperature. Then, the charred materials were grinded and passed through a $0.5 \mathrm{~mm}$ sieve. The chemical properties (Table 2) of sieved BPB was analyzed in INARS laboratory under Bangladesh Council of Scientific and Industrial Council 
(BCSIR) and applied into the soil to evaluate the growth of Ipomoea aquatica.

\section{Experimental layout}

Fifteen earthen pots (2-L) were collected for this experiment. One kg soil was poured into each pot. Three rates (1, 2 and $3 \% \mathrm{w} / \mathrm{w}$ ) of BPB were applied in soil as treatment along with control (no BPB) and three replications for each treatment. After mixing of BPB into the soil, the pots were kept in field capacity for 7 days. Then, the seeds of Ipomoea aquatica, collected from local market, were sown in each pot. Only tap water was used for irrigation when it was needed and same volume of water was applied for all the pots. The plants were thinned when it was grown enough. No pest attack was observed during the growth period. Fortytwo days after seed sowing the plants were harvested by cutting the stems about $2-\mathrm{cm}$ above the ground. Different growth parameters were measured and recorded.

Biochar from banana peel waste was highly rich with potassium (K) content (Table 2) which can be used as a source of $\mathrm{K}$ for plants in field. Another separate pot experiment was also conducted to evaluate the efficiency of BPB to recover K. Nine earthen pots (2-L) were collected for this experiment. One $\mathrm{kg}$ fresh sand after washing with distilled water was poured into each pot. Banana peel biochar and $\mathrm{KCl}$ were applied for $\mathrm{K}$ source in sand medium as treatment along with control (neither $\mathrm{BPB}$ nor $\mathrm{KCl}$ ) and three replications for each treatment. Potassium was applied as rated $10 \mathrm{tha}^{-1}$ and BPB was also applied as required amount by adjusting with $\mathrm{K}$ fertilizer considering the $\mathrm{K}$ content in BPB. Then, seeds of Cucurbita moschata as experimental plant were collected and sown in each pot to run the experiment. Cucurbita moschata is a high $\mathrm{K}$ demanding crop that is why it was selected for this experiment to observe the $\mathrm{K}$ deficiency symptoms clearly. Seedlings were irrigated in every day by same volume of water at same time. Finally, seedlings were allowed to grow to observe the $\mathrm{K}$ deficiency symptoms in the growing plants.

\section{Laboratory analyses}

Soil textural class was determined by hydrometer method using Marshal Triangle (Gee and Bauder 1986). Soil pH and EC was measured as soil:water ratio 1:2.5 (Jackson 1973). Total nitrogen of the soil and BPB were determined by Micro-Kjeldahl method following $\mathrm{H}_{2} \mathrm{SO}_{4}$ acid digestion as suggested by Jackson (1973). Soil organic matter was determined by wet oxidation with potassium dichromate and sulfuric acid system (Walkley and Black 1934). Available phosphorus was extracted from the soil with $0.5 \mathrm{M} \mathrm{NaHCO}_{3}$ at $\mathrm{pH} 8.5$ (Jackson 1973) and $p$ was determined by ascorbic acid blue color method (Murphy and Riley 1962). Total Na,
$\mathrm{K}, \mathrm{Ca}, \mathrm{Mg}, \mathrm{Mn}, \mathrm{Zn}, \mathrm{Fe}$ concentration of BPB was measured through digestion with concentrated $\mathrm{HNO}_{3}$ and $\mathrm{HCl}$ (1:3) acid system, by Atomic Absorption Spectrophotometer (Imamul Huq and Alam 2005).

\section{Statistical analyses}

Statistical analyses were performed using SPSS 13.0 version and MS Excel 2010 software. Graphs were drawn using OriginPro8 (Origin Lab, Northampton, MA, USA). Analysis of variance (ANOVA) was used to test the BPB treatment effects on plant growth parameters as height, leaf number, fresh weight and dry weight (SPSS 2004). The least significant difference (LSD at $p=0.05$ ) test was applied to assess the differences between treatment means $(n=3)$.

\section{Results and discussion}

\section{Effects of BPB application on plant height, leaf number and plant biomass of Ipomoea aquatica}

Height of Ipomoea aquatic under 1 and 2\% BPB treatments was reduced significantly $(p<0.05)$ but plant height in $3 \%$ BPB treatment was increased again but statistically insignificant $(p<0.05)$ as compared to control (Fig. 1). However, there was no significant $(p<0.05)$ effect of BPB treatments on plant height (Figs. 1, 2a, b, c). Whereas leaf number were increased in 2 and 3\% BPB application, but reduced in $1 \%$ treatment compared to control (Fig. 1). Leaf number in 2 and $3 \%$ BPB treatments was promoted significantly $(p<0.05)$ compared to $1 \%$ BPB application and control. Plant fresh weight was promoted about 9.86 and $3.23 \%$ in 2 and $3 \%$ BPB treatments, respectively, but reduced about $22.08 \%$ in $1 \%$ BPB application compared to control (Fig. 3). Apart from fresh weight, dry weight was also increased about 18.24 and $12.08 \%$ under 2 and 3\% BPB treatments, respectively, but attenuated about $9.90 \%$ in $1 \%$ BPB treatment compared to control (Fig. 3). Although both fresh and dry weight were increased under 2 and 3\% BPB treatments and decreased for $1 \%$ BPB treatment but results were not statistically significant $(p<0.05)$.

Our present research findings were coincidence with other previous researcher (Helliwell 2015; Tian et al. 2017). Helliwell (2015) suggested that the addition of biochar had no apparent effect on plant growth. Tian et al. (2017) described that there was no significant effects of biochar addition on plant total fresh mass, leaf mass, root fresh mass, root dry mass up to $16 \%$ biochar treatment. But higher percentage of biochar (4-32\%) addition than our research (1-3\%) had significant effects on plant total fresh weight, leaf weight, root fresh weight, root dry weight (Tian et al. 2017). Above-ground biomass and 

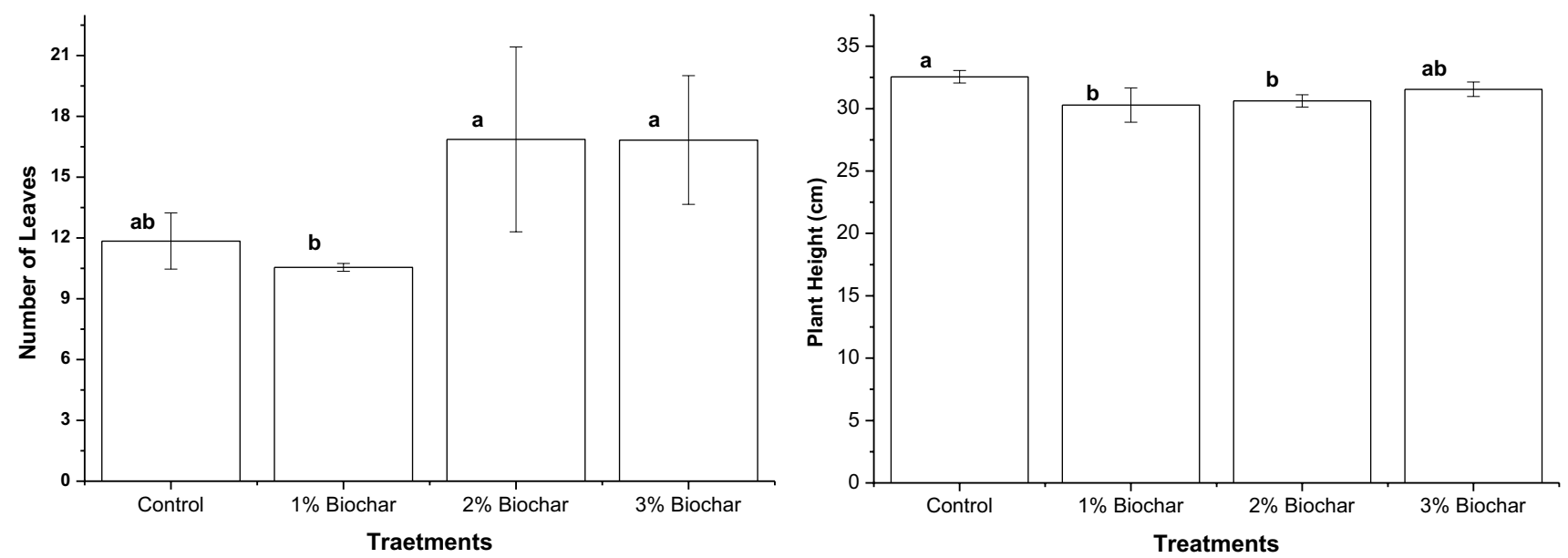

Fig. 1 Effects of BPB on plant height and leaf number of Ipomoea aquatica (Different letters indicate significantly different among the means)
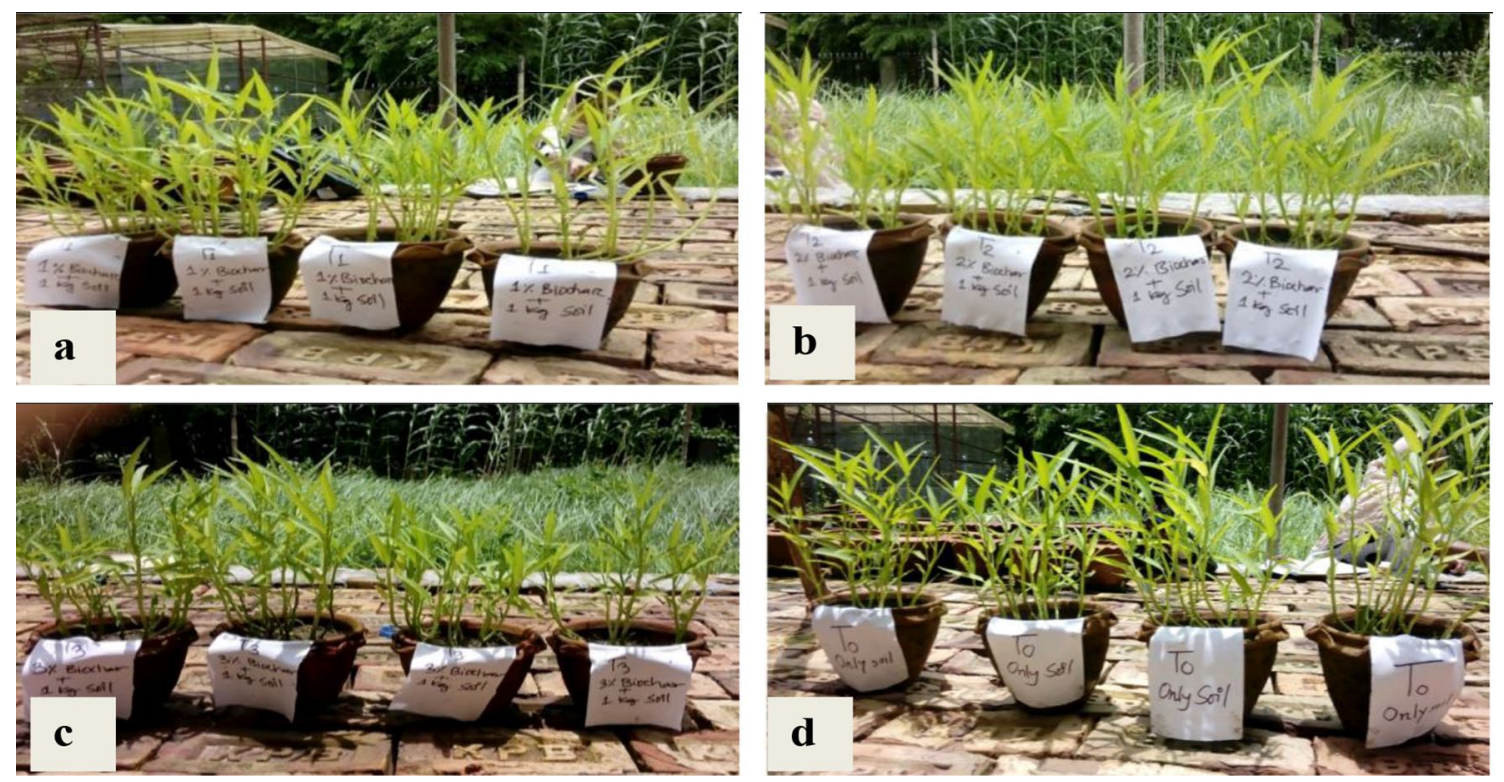

Fig. 2 Visual observation of growth performance of Ipomoea aquatica due to different rates of BPB application. In a, b, c, and $\mathbf{d}$ is $1 \%, 2 \%, 3 \%$ BPB and control treatments, respectively

below-ground biomass were increased significantly compared to control at higher percentage of biochar ( $>3 \%)$ addition than our research (Carter et al. 2013; Tian et al. 2017). Trupiano et al. (2017) showed after 5 weeks of plantation, there was no significant effect of biochar addition on plant leaf width, perimeter, length and area as well as all the agronomic parameters were altered at identical rate. Biochar can increase above-ground and below-ground biomass in some circumstances, for example higher percentage of biochar addition or different sources of biochar addition (Helliwell 2015). But in our experiment, source of biochar production was not significant, because we used only banana peel as source of biochar production
(N: $9.5 \mathrm{~g} \mathrm{~kg}^{-1}, \mathrm{~K}: 42.55 \%$ ), but some researcher used rice husk; $\mathrm{N}: 6.5 \mathrm{~g} \mathrm{~kg}^{-1}, \mathrm{~K}: 14 \%$ (Carter et al. 2013), pinewood, $\mathrm{N}: 5.44 \mathrm{~g} \mathrm{~kg}^{-1}$, P: $0.65 \mathrm{~g} \mathrm{~kg}^{-1}, \mathrm{~K}: 1.64 \%$ (Tian et al. 2017), orchard pruning biomass, $\mathrm{N}: 9.1 \mathrm{~g} \mathrm{~kg}^{-1}, \mathrm{P}$ : $12.2 \mathrm{~g} \mathrm{~kg}^{-1}$ (Trupiano et al. 2017), etc. as sources of biochar production. Chemical properties among the used biochar by different researcher were apparently different, but nitrogen percentage is important for above-ground biomass production which was varied in little extent. In the current research, plant biomass under BPB treatments increased in little extent compared to control but not significantly $(p<0.05)$ which might be due to lower percentage of BPB addition. 

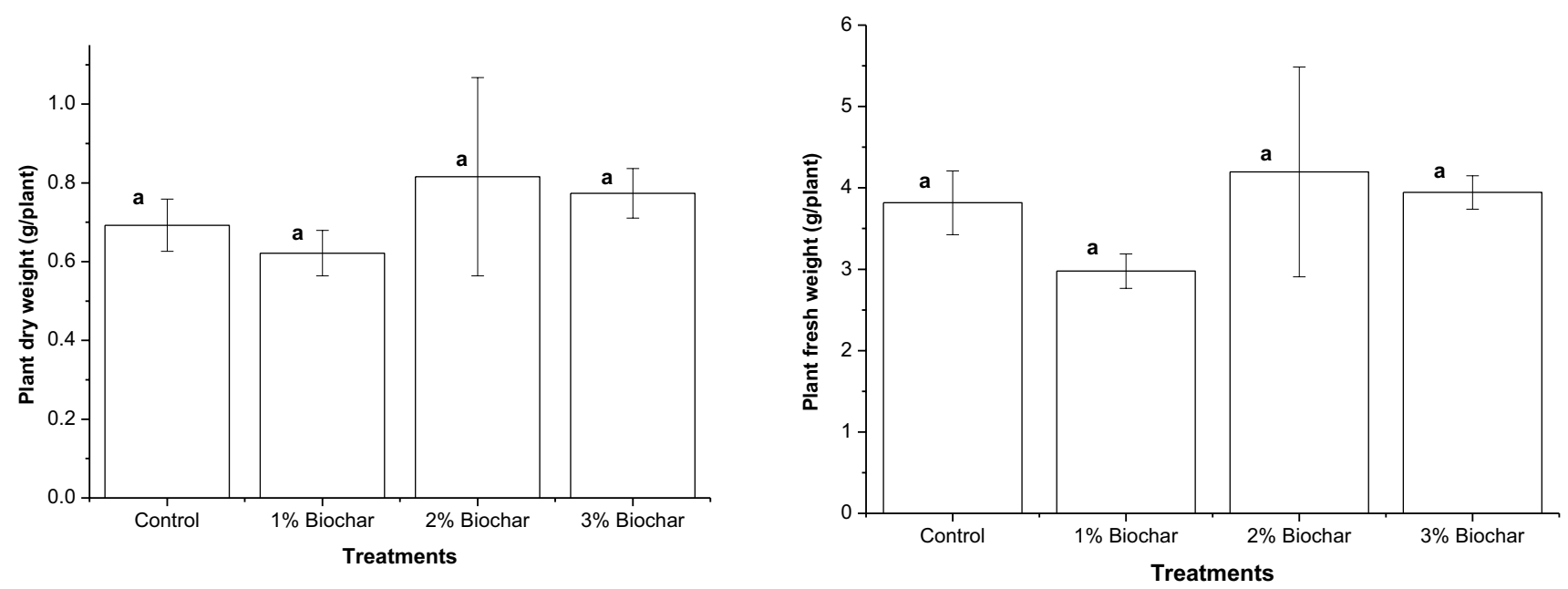

Fig. 3 Effects of BPB on plant biomass (Different letters indicate significantly different among the means)

\section{Effects of BPB as K supplemental on Cucurbita moschata}

Potassium deficiency symptoms were clearly observed in plants grown in sand medium without addition of any $\mathrm{K}$ (Fig. 4a). Whereas there was no such K deficiency symptoms were observed in plants grown in the same medium irrespective to $\mathrm{K}$ sources (KCl, Fig. 4b; BPB, Fig. 4c). Moreover, the plants were more healthy, greener and stronger when treated with BPB than control and $\mathrm{KCl}$-treated plants (Fig. 4). But the plants treated with $\mathrm{KCl}$ were seemed to be weaker and shorter than others. The reason might be the excess $\mathrm{K}$ in the growth medium which blocks the absorption of other elements such as $\mathrm{Ca}, \mathrm{Mg}, \mathrm{Zn}$ and $\mathrm{Fe}$ (Brady and Weil 2017). Experimental evidence (Fig. 4) proved BPB as
K-rich amendment. In this experiment, $\mathrm{K}$ deficiency was observed directly in a separate sand culture (Fig. 4). From the current experimental evidence, it was clear that BPB might be a good source of $\mathrm{K}$ amendment and could be used as a source of $\mathrm{K}$ instead of chemical fertilizer for sustainable agriculture.

\section{Conclusion}

The experimental results revealed that BPB application below threshold limit $(<4 \%)$ improved the plant productivity compared to control but not significantly $(p<0.05)$. But a chemical property of BPB was proved as a potential source of K. Visual observation under a separate experiment

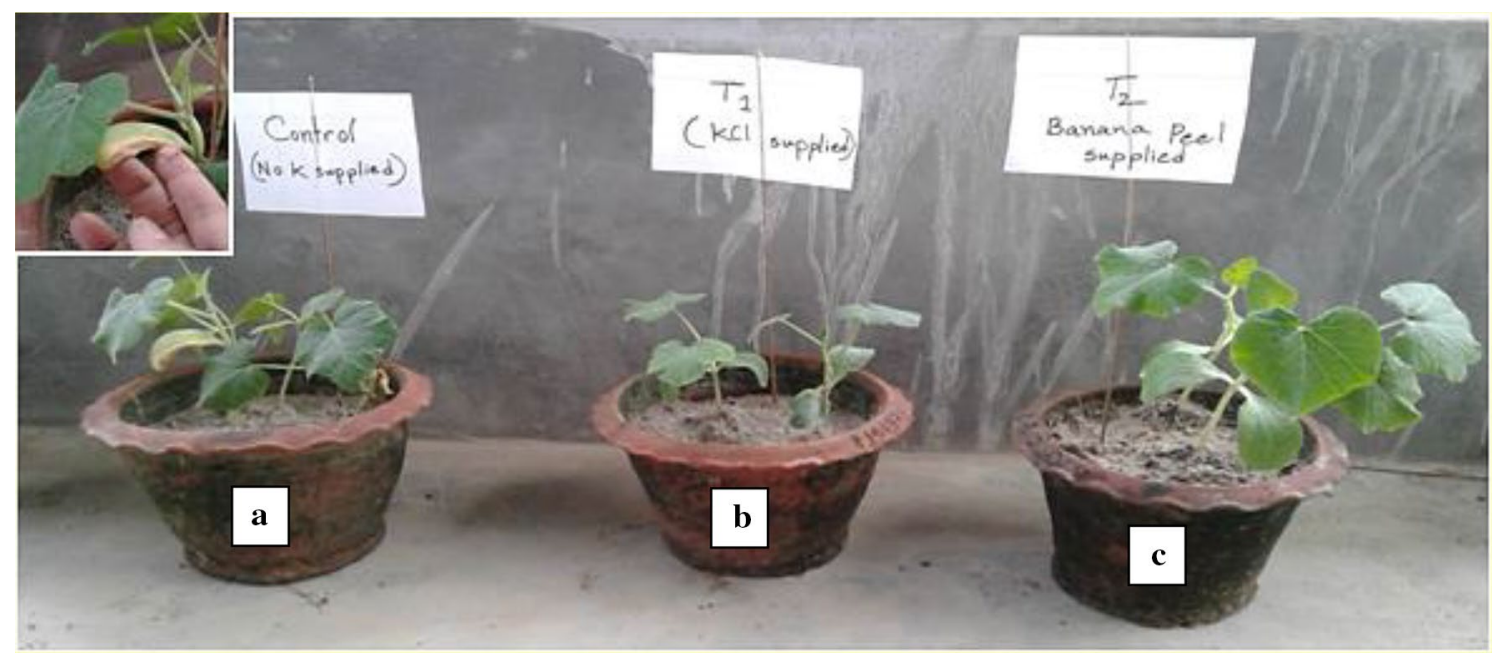

Fig. 4 Visual observation of $\mathrm{K}$ deficiency symptom in Cucurbita moschata $(\mathrm{a}=$ control, $\mathrm{b}=\mathrm{K}$ from $\mathrm{KCl}, \mathrm{c}=\mathrm{K}$ from $\mathrm{BPB})$ 
demonstrated the evidence of BPB as an alternative source of $\mathrm{K}$ for sustainable agriculture.

Acknowledgements The authors are grateful to Soil, Water and Environment Discipline of Khulna University, Bangladesh and Bangladesh Council of Scientific and Industrial Research (BCSIR) for providing experimental facilities and analytical facilities, respectively.

\section{Compliance with ethical standards}

Conflict of interest The authors declare that they have no conflict of interest.

Open Access This article is distributed under the terms of the Creative Commons Attribution 4.0 International License (http://creativeco mmons.org/licenses/by/4.0/), which permits unrestricted use, distribution, and reproduction in any medium, provided you give appropriate credit to the original author(s) and the source, provide a link to the Creative Commons license, and indicate if changes were made.

\section{References}

Alburquerque JA, Salazar P, Barrón V, Torrent J, del Campillo MDC, Gallardo A, Villar R (2013) Enhanced wheat yield by biochar addition under different mineral fertilization levels. Agron Sustain Dev 33(3):475-484

Asai H, Samson BK, Stephan HM, Songyikhangsuthor K, Homma K, Kiyono Y, Inoue Y, Shiraiwa T, Horie T (2009) Biochar amendment techniques for upland rice production in Northern Laos: 1. soil physical properties, leaf SPAD and grain yield. Field Crop Res 111(1-2):81-84. https://doi.org/10.1016/j.fcr.2008.10.008

Biederman LA, Harpole WS (2013) Biochar and its effects on plant productivity and nutrient cycling: a meta-analysis. GCB Bioenergy 5(2):202-214. https://doi.org/10.1111/gcbb.12037

Bonanomi G, Ippolito F, Scala F (2015) A "black" future for plant pathology? Biochar as a new soil amendment for controlling plant diseases. J Plant Pathol 97(2):223-234. https://doi.org/10.4454/ jpp.v97i2.3381

Brady NC, Weil RR (2017) The nature and properties of soils, 15th edn. Pearson Education Limited, England ISBN 978-0-13-325448-8

Carter S, Shackley S, Sohi S, Suy TB, Haefele S (2013) The impact of biochar application on soil properties and plant growth of pot grown lettuce (Lactuca sativa) and cabbage (Brassica chinensis). Agronomy 3(2):404-418. https://doi.org/10.3390/agronomy30 20404

Gee GW, Bauder JW (1986) Particle size analysis. In: Klute A (ed) Methods of soil analysis. Part 1, physical and mineralogical methods, agronomy monograph no. 9, 2nd edn. ASA and SSSA, Madison, pp 383-409

Hammond J, Shackley S, Prendergast-Miller M, Cook J, Buckingham S, Pappa VA (2013) Biochar field testing in the UK: outcomes and implications for use. Carbon Manag 4(2):159-170. https:// doi.org/10.4155/cmt.13.3

Helliwell R (2015) Effect of biochar on plant growth. Arboric J 37(4):238-242. https://doi.org/10.1080/03071375.2015.1125601

Hossain MF (2014) A study of banana production in Bangladesh: area, yield and major constraints. ARPN J Agric Biol Sci 9:206-210

IBI (International Biochar Initiative) (2012) Standardized product definition and product testing guidelines for biochar that is used in soil. IBI biochar stand. http://www.biochar-international.org/sites/
default/files/Guidelinesfor Biochar That Is Used in Soil Final.Pdf. Accessed 10 Jan 2019

Imamul Huq SM, Alam MD (2005) A handbook on analyses of soil, plant and water. BACER-DU, University of Dhaka, Bangladesh

Jackson ML (1973) Soil chemical analysis. Prentice Hall of India Pvt. Ltd, New Delhi, p 498

Ledividich J, Geoffroy F, Canope I, Chenost M (1976) Using waste bananas as animal feed. World Anim Rev 20:22-30

Lohmann R, MacFarlane JK, Gschwend PM (2005) Importance of black carbon to sorption of native PAHs, PCBs, and PCDDs in Boston and New York harbor sediments. Environ Sci Technol 39(1):141-148. https://doi.org/10.1021/es049424

Lu H, Li Z, Fu S, Méndez A, Gascó G, Paz-Ferreiro J (2015) Effect of biochar in cadmium availability and soil biological activity in an anthrosol following acid rain deposition and aging. Water Air Soil Pollut 226(5):164-174. https://doi.org/10.1007/s1127 0-015-2401-y

Marris E (2006) Putting the carbon back: black is the new green. Nature 442(7103):624-626. https://doi.org/10.1038/442624a

Mohan D, Pittman CU Jr, Bricka M, Smith F, Yancey B, Mohammad J, Steele PH, Alexandre-Franco MF, Gómez-Serrano V, Gong H (2007) Sorption of arsenic, cadmium, and lead by chars produced from fast pyrolysis of wood and bark during bio-oil production. J Colloid Interface Sci 310(1):57-73. https://doi.org/10.1016/j. jcis. 2007.01 .020

Murphy J, Riley JP (1962) A modified single solution method for the determination of phosphate in natural water. Anal Chim Acta 27:31-36. https://doi.org/10.1016/S0003-2670(00)88444-5

Novak JM, Lima I, Xing B, Gaskin JW, Steiner C, Das KC, Ahmedna M, Rehrah D, Watts DW, Busscher WJ, Schomberg H (2009) Characterization of designer biochar produced at different temperatures and their effects on a loamy sand. Ann Environ Sci 3:195-206 ISSN 1939-2621

Novak JM, Busscher WJ, Watts DW, Amonette JE, Ippolito JA, Lima IM, Gaskin J, Das KC, Steiner C, Ahmedna M, Rehrah D (2012) Biochars impact on soil-moisture storage in an ultisol and two aridisols. Soil Sci 177(5):310-320. https://doi.org/10.1097/ SS.0b013e31824e5593

Qian L, Li Q, Sun J, Feng Y (2018) Effect of biochar on plant growth and aluminium form of soil under aluminium stress. In: IOP conference series: earth and environmental science 108(4):042123. IOP Publishing. https://doi.org/10.1088/1755-1315/108/4/042123

Reverchon F, Flicker RC, Yang H, Yan G, Xu Z, Chen C, Bai SH, Zhang D (2014) Changes in $\delta 15 \mathrm{~N}$ in a soil-plant system under different biochar feedstocks and application rates. Biol Fertil Soils 50(2):275-283. https://doi.org/10.1007/s00374-013-0850-2

Sika MP, Hardie AG (2014) Effect of pine wood biochar on ammonium nitrate leaching and availability in a South African sandy soil. Eur J Soil Sci 65(1):113-119. https://doi.org/10.1111/ejss.12082

Sohi SP, Krull E, Lopez-Capel E, Bol R (2010) A review of biochar and its use and function in soil. Adv Agron 105:47-82. https:// doi.org/10.1016/S0065-2113(10)05002-9

SPSS (2004) SPSS 13.0 for windows. SPSS Inc., Chicago ISBN 0-13-154242-7

Trupiano D, Cocozza C, Baronti S, Amendola C, Vaccari FP, Lustrato G, Di Lonardo S, Fantasma F, Tognetti R, Scippa GS (2017) The effects of biochar and its combination with compost on lettuce (Lactuca sativa L.) growth, soil properties, and soil microbial activity and abundance. Int J Agron 2017:3158207. https://doi. org/10.1155/2017/3158207

United States Department of Agriculture (USDA) (1951) Soil survey manual. Soil survey staff, bureau of plant industry, soils and agricultural engineering, USDA, handbook-18. Washington

Van Zwieten L, Kimber S, Morris S, Chan KY, Downie A, Rust J, Joseph S, Cowie A (2010) Effects of biochar from slow pyrolysis of papermill waste on agronomic performance and soil fertility. 
Plant Soil 327(1-2):235-246. https://doi.org/10.1007/s1110 4-009-0050- $\mathrm{x}$

Ventura F, Salvatorelli F, Piana S, Pieri L, Pisa PR (2012) The effects of biochar on the physical properties of bare soil. Earth Environ Sci Trans R Soc Edinb 103(1):5-11. https://doi.org/10.1017/ S1755691012000059

Walkley A, Black IA (1934) An examination of degtjareff method for determining soil organic matter and a proposed modification of the chromic acid titration method. Soil Sci 37(1):29-37. https:// doi.org/10.1097/00010694-193401000-00003

Warnock DD, Lehmann J, Kuyper TW, Rillig MC (2007) Mycorrhizal responses to biochar in soil-concepts and mechanisms. Plant Soil 300(1-2):9-20. https://doi.org/10.1007/s11104-007-9391-5

Waters D, Van Zwieten L, Singh BP, Downie A, Cowie AL, Lehmann J (2011) Biochar in soil for climate change mitigation and adaptation. Soil Health Clim Chang 29:345-368
Tian D, Liu A, Xiang Y (2017) Effects of biochar on plant growth and cadmium uptake: case studies on Asian Lotus (Nelumbo nucifera) and Chinese Sage (Salvia miltiorrhiza). In: Huang WJ (ed) Engineering applications of biochar. IntechOpen, London. https://doi. org/10.5772/intechopen.68251

Publisher's Note Springer Nature remains neutral with regard to jurisdictional claims in published maps and institutional affiliations. 